\title{
Magnetic behavior of solid solutions $\operatorname{REMe}_{0.50} \mathrm{Mn}_{0.50} \mathrm{O}_{3}(\mathrm{RE}=\mathrm{Y}, \mathrm{La}, \mathrm{Pr}, \mathrm{Nd}, \mathrm{Eu}, \mathrm{Gd}, \mathrm{Er} ; \mathrm{Me}=\mathrm{Ni}, \mathrm{Co})$
}

\author{
O. PEÑA ${ }^{1}$, P. BARAHONA ${ }^{2}$, V. GIL ${ }^{3}$, J. TARTAJ ${ }^{3}, C$. MOURE $^{3}$
}

\author{
'Sciences Chimiques de Rennes, UMR 6226, Université de Rennes 1, 35042 Rennes, France \\ 2 Instituto de Ciencias Básicas, Universidad Católica del Maule, Talca, Chile \\ ${ }^{3}$ Instituto de Cerámica y Vidrio, CSIC, Electroceramics Department, 28049 Madrid, Spain
}

\begin{abstract}
Partial substitution of $\mathrm{Mn}$ by a divalent metal in rare-earth manganites $\mathrm{REMe}_{\mathrm{x}} \mathrm{Mn}_{1-\mathrm{x}} \mathrm{O}_{3}$ results in the simultaneous presence of $\mathrm{Mn}^{3+}$ and $\mathrm{Mn}^{4+}$. The RE sublattice has its own properties and can interact with the local field imposed by the ferromagnetic Mn network. Its orientation differs depending on the RE nature, adopting a parallel direction with respect to the local field, or it may align in opposite direction, resulting in uncompensated antiferromagnetic structure.

For divalent elements (e.g., $\mathrm{Ni}^{2+}$ ), the solid solution is limited to $\mathrm{RENi}^{2+}{ }_{0.5} \mathrm{Mn}^{4+}{ }_{0} \mathrm{O}_{3}$; at this frontier composition, the ferromagnetic superexchange $\mathrm{Ni}^{2+}-\mathrm{O}-\mathrm{Mn}^{4+}$ interactions are optimized. For $\mathrm{Me}=\mathrm{Co}$, this limit can be extended, meaning that part of cobalt takes a 3+ state ; in this case, presence of $\mathrm{Co}^{3+}$ modifies the magnetic coupling, leading to qualitatively different behaviours during the ZFC/FC cycles. In this work, we have chosen the specific composition $\mathrm{REMe}_{0.50} \mathrm{Mn}_{0.50} \mathrm{O}_{3}$ for which the strongest magnetic interactions are expected, emphasizing the results obtained for $\mathrm{Me}=\mathrm{Ni}$ and $\mathrm{Co}$ and comparing various rare-earth elements $(\mathrm{RE}=\mathrm{Y}, \mathrm{La}, \mathrm{Pr}, \mathrm{Nd}, \mathrm{Eu}, \mathrm{Gd}$ and $\mathrm{Er})$. As expected from the general behaviour of the series (RE, Ca) $\mathrm{MnO}$, we find that in the $\mathrm{RE}(\mathrm{Mn}, \mathrm{Me}) \mathrm{O}_{3^{\prime}}$, the larger the $\mathrm{RE}$ ionic radius, the highest the transition temperature, reaching $235 \mathrm{~K}$ in $\mathrm{LaCo}_{0.50} \mathrm{Mn}_{0.50} \mathrm{O}_{3}$ compared to $68 \mathrm{~K}$ in $\mathrm{ErCo}_{0.50} \mathrm{Mn}_{0.50} \mathrm{O}_{3}$.
\end{abstract}

Keywords: Ferromagnetism, Magnetic coupling, Spin Reversal.

Comportamiento magnético de las soluciones sólidas TRMe ${ }_{0.50} \mathrm{Mn}_{0.50} \mathrm{O}_{3}(\mathrm{TR}=\mathrm{Y}, \mathrm{La}, \mathrm{Pr}, \mathrm{Nd}, \mathrm{Eu}, \mathrm{Gd}, \mathrm{Er} ; \mathrm{Me}=\mathrm{Ni}, \mathrm{Co})$

La sustitución parcial de Mn por un catión divalente en manganitas de tierras raras $\mathrm{TRMe}_{\mathrm{x}} \mathrm{Mn}_{1-\mathrm{x}} \mathrm{O}_{3}$ induce la presencia simultánea de $\mathrm{Mn}^{3+}$ y Mn ${ }^{4+}$. La subred TR tiene sus propiedades intrínsecas y puede interactuar con el campo local impuesto por la red ferromagnética del Mn. Su orientación difiere dependiendo de la naturaleza de la TR, adoptando una dirección paralela con respecto al campo local, o puede alinearse en sentido opuesto, produciendo una estructura antiferromagnética no compensada.

Para cationes divalentes $\left(\mathrm{Ni}^{2+}\right)$, la solución sólida está limitada a $\mathrm{TRNi}{ }_{0}^{2+} \mathrm{Mn}^{4+}{ }_{05} \mathrm{O}_{3}$; en este límite, las interacciones de supercanje $\mathrm{Ni}^{2+}-\mathrm{O}-\mathrm{Mn}^{4+}$ se optimizan. Para $\mathrm{Me}=\mathrm{Co}$ el límite se amplía a causa de que el cobalto puede tomar el estado 3+; en este caso, la presencia de $\mathrm{Co}^{3+}$ modifica el acoplamiento magnético llevando a comportamientos cualitativamente diferentes durante los ciclos ZFC/FC. En el presente trabajo se ha escogido la composición específica TRMe ${ }_{0.50} \mathrm{Mn}_{0.50} \mathrm{O}_{3}$ para la cual se esperan las interacciones magnéticas más intensas, remarcando los resultados obtenidos para $\mathrm{Me}=\mathrm{Ni}$ y Co y comparando varios elementos de tierras raras $(\mathrm{TR}=\mathrm{Y}, \mathrm{La}, \mathrm{Pr}, \mathrm{Nd}, \mathrm{Eu}, \mathrm{Gd}$ y $\mathrm{Er}$ ). Como se esperaba de acuerdo con el comportamiento general de las soluciones sólidas (TR,Ca) $\mathrm{MnO}_{3^{\prime}}$, se ha hallado que en las series TR(Mn,Me) $\mathrm{O}_{3^{\prime}}$ cuanto mayor es el radio iónico de la TR mayor es la temperatura de transición, alcanzando $235 \mathrm{~K}$ para composiciones $\mathrm{LaCo}_{0.50} \mathrm{Mn}_{0.50} \mathrm{O}_{3}$ frente a $68 \mathrm{~K}$ para $\mathrm{ErCo}_{0.50} \mathrm{Mn}_{0.50} \mathrm{O}_{3}$.

Palabras clave: Ferromagnetismo, acoplamiento magnético, inversión de espin.

\section{INTRODUCTION}

The discovery of giant magneto-resistance in manganese oxides has resulted in a renewed interest in mixed-valence manganese perovskites over the last decades because of the many possible technological applications and the very interesting physics coming from the inter-relation between structural, magnetic and transport properties (1-3). Most of these works describe the physico-chemical properties of doped $\mathrm{ABO}_{3}$ perovskites, where the A-site, occupied by a rare-earth element $\mathrm{RE}$, is partially substituted by an alkalineearth. It is also possible to partially substitute the B site occupied by the mixed-valent manganese, and thus create similar transformations in the Mn oxidation state (from $\mathrm{Mn}^{3+}$ to $\mathrm{Mn}^{4+}$ ), triggering the exchange interactions responsible of ferromagnetic order and its associated metal-insulator transition (4).

In recent years we have been studying the magnetic properties of several perovskites of formula $\mathrm{RE}(\mathrm{Me}, \mathrm{Mn}) \mathrm{O}_{3}$ in which the $\mathrm{Mn}$ atom has been substituted by a transitionmetal element, like $\mathrm{Cu}, \mathrm{Ni}$ or $\mathrm{Co}$. Interesting results have been obtained, for instance, when the rare-earth element bears a high magnetic moment since it may interact with the ordered Mn-sublattice (5). As such, spectacular behaviours 
have been observed by us in the case of $\mathrm{RE}=\mathrm{Er}$, for which the magnetization loops present two important anomalies : a step-like transition and an intersection of the increasing and decreasing branches of the magnetization loops $\mathrm{M}(\mathrm{H})$ $(6,7)$. These phenomena are especially evident at the particular composition Co:Mn = 1:1 $\left(\mathrm{ErCo}_{0.50} \mathrm{Mn}_{0.50} \mathrm{O}_{3}\right)$ where ferromagnetic $\mathrm{Co}^{2+}-\mathrm{Mn}^{4+}$ interactions are maximized and for which a cation and charge ordering may be expected (8). It becomes then interesting to compare the magnetic behaviour of different rare-earth manganese perovskite at this particular composition since the rare-earth nature (ionic radius and intrinsic magnetic moment) should be a critical factor in setting different types of magnetic interactions. Several authors have examined these series, without going deeply into the magnetic ordering features $(9,10)$.

So, in this work we compare a specific composition, for which the substitution rate was 1:1 between manganese and the transition metal Me. This latter was chosen to be Ni and $\mathrm{Co}$, because different exchange interaction mechanisms were supposed to exist between $\mathrm{Mn}^{4+}$ or $\mathrm{Mn}^{3+}$ with respect to $\mathrm{Ni}^{2+}, \mathrm{Co}^{2+}$ or $\mathrm{Co}^{3+}$. Results for various rare-earth elements $(\mathrm{RE}=\mathrm{Y}, \mathrm{La}, \mathrm{Pr}, \mathrm{Nd}, \mathrm{Eu}, \mathrm{Gd}$ and $\mathrm{Er})$ are reported herein. Our main goal is to look at the influence of the rare-earth nature into the magnetic properties, which we expect to be strongly dependent on the concentration and the oxidation state of the transition metal substitute.

\section{EXPERIMENTAL PROCEDURE}

Solid solutions were prepared by classical solid state methods (except in the case of $\mathrm{LaCo}_{0.50} \mathrm{Mn}_{0.50} \mathrm{O}_{3^{\prime}}$ for which soft chemistry techniques were applied (11]), using submicronic powder oxides $\mathrm{RE}_{2} \mathrm{O}_{3}, \mathrm{MnO}$ and $\mathrm{Co}_{3} \mathrm{O}_{4}$. The mixtures were mixed and homogenized by attrition milling with zirconia balls, using isopropanol as liquid medium, then calcined and re-milled three times to assure a total reaction. The thermal cycle consisted of a heating rate of $5{ }^{\circ} \mathrm{C} / \mathrm{min}$ reaching the reaction temperature of $1150{ }^{\circ} \mathrm{C}$, held for $6 \mathrm{~h}$ and then cooled at $1{ }^{\circ} \mathrm{C} / \mathrm{min}$. Sintering was usually performed under oxygen flow, keeping an approximate rate of $5{ }^{\circ} \mathrm{C} / \mathrm{min}$ during warming, holding the specimens for 2 hours at $1250{ }^{\circ} \mathrm{C}$, and then cooling at approximately $0.5-1{ }^{\circ} \mathrm{C} / \mathrm{min}$. Samples were characterized by $\mathrm{X}$-ray diffraction techniques both before and after the sintering conditions, confirming the presence of a pure perovskite orthorhombic Pbnm structure. At this point we should briefly recall the solubility regimes of these materials: when substituting $\mathrm{Mn}^{3+}$ by $\mathrm{Ni}^{2+}$, the solid solution attains a maximum substitution rate of $x(\mathrm{Ni})=0.50$, since all manganese is converted into $\mathrm{Mn}^{4+}$, further nickel content showing up as secondary phases (12). In the case of Co, the solid solution can be extended further, provided special sintering conditions are respected, in particular slow cooling under oxygen atmosphere ; in this way, $\mathrm{Co}^{3+}$ and $\mathrm{Co}^{2+}$ ions may coexist in the system, together with $\mathrm{Mn}^{4+}(13)$.

Magnetic measurements were performed in a Quantum Design MPMS-XL5 SQUID susceptometer, between $2 \mathrm{~K}$ and $300 \mathrm{~K}$ and as a function of the applied field, from $-50 \mathrm{kOe}$ up to $+50 \mathrm{kOe}$. All measurements were done in specimens cut from ceramic bulks and glued to calibrated gelatin sample holder, thus avoiding any disorientation due to torque forces exerted on the sample. The ordered regime was investigated by performing magnetization cycles as a function of temperature (ZFC/FC cycles) and applied fields (magnetization loops at $2 \mathrm{~K}$ ).

\section{RESULTS AND DISCUSSION}

\subsection{Light rare-earth elements}

Typical examples of ZFC/FC cycles for $\mathrm{REMe}_{0.50} \mathrm{Mn}_{0.50} \mathrm{O}_{3}$ $(\mathrm{Me}=\mathrm{Ni}$ and $\mathrm{Co})$ are shown on figure 1, in the case of light rare-earth elements, like yttrium or neodymium. Several features can be remarked. Firstly, there is an obvious dependence of the ordering temperature $\mathrm{T}_{\mathrm{c}}$ with the $\mathrm{RE}^{3+}$ ionic radii, varying from approximately $85 \mathrm{~K}$ up to $170 \mathrm{~K}$ when $r_{\mathrm{Y}}$ $=1.019 \AA$ and $r_{\mathrm{Nd}}=1.109 \AA$, respectively (14). This behavior is well known in the series ( $\mathrm{RE}, \mathrm{Ca}) \mathrm{MnO}_{3^{\prime}}$, as it is directly related with the deformation of the perovskite lattice by varyingsize lanthanide elements situated at the A site of the $\mathrm{ABO}_{3}$ structure (15).

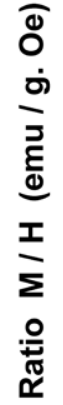
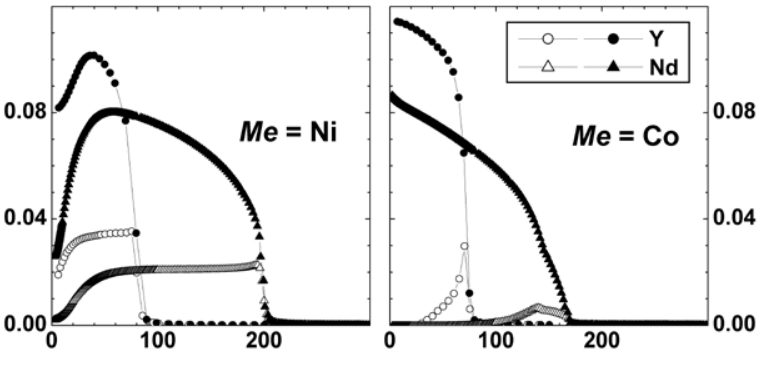

Temperature (K)

Fig. 1- ZFC (open symbols) / FC (filled symbols) magnetization cycles, measured at $250 \mathrm{Oe}$, for $\mathrm{REMe}_{0.50} \mathrm{Mn}_{0.50} \mathrm{O}_{3}(\mathrm{RE}=\mathrm{Y}$ and $\mathrm{Nd})$. Ciclos de imanación ZFC (símbolos abiertos) / $/ .50$ ( (símbolos cerrados), medidos a 250 Oe para $\mathrm{TRMe}_{0.50} \mathrm{Mn}_{0.50} \mathrm{O}_{3}(\mathrm{TR}=\mathrm{Y}$ y Nd$)$

The second feature to be remarked is the qualitatively different behavior for cobalt-substituted or nickel-substituted solid solutions. In the first case, the ZFC procedure (that is, when warming the sample under a low applied field, after being cooled under zero field) leads to a rather sharp peak, characteristic of canted-type antiferromagnetism (16). In the second case, the ZFC section is characterized by a broad plateau collapsing at the transition temperature $T_{c}$; this different behavior was also observed in a.c. susceptibility measurements in the case of $\mathrm{Y}(\mathrm{Me}, \mathrm{Mn}) \mathrm{O}_{3}(\mathrm{Me}=\mathrm{Ni}, \mathrm{Co})(17)$ and seems to be a characteristic feature closely connected to the different nature of the ferromagnetic interactions between $\mathrm{Co}^{2+}$ and $\mathrm{Mn}^{4+}$, from one side, and $\mathrm{Ni}^{2+}$ and $\mathrm{Mn}^{4+}$, on the other side.

A third feature which should be remarked in figure 1, since it appears systematically in other examples of these two families, is the fact that nickel-based compounds show an abrupt variation of both ZFC and FC modes at low temperatures, while the cobalt-based compounds have their FC magnetization continuously increasing (or reaching a constant value) when decreasing the temperature. This abrupt change at low temperature should not be associated to any antiferromagnetic exchange interaction between sublattices, as we shall discuss below for heavy rare-earth elements, since it also occurs for non magnetic yttrium (fig. 1, left-hand panel). Such a break may be associated to antiferromagnetic interactions within the $\mathrm{Mn} / \mathrm{Ni}$ lattice, as observed by neutron diffraction measurements performed in $\mathrm{YNi}_{0.50} \mathrm{Mn}_{0.50} \mathrm{O}_{3}$ (8). On the other hand, the general behavior observed in the cobaltbased systems, as shown in figure 1 for the case of $\mathrm{Y}$ and 
$\mathrm{Nd}$, is confirmed in figure 2 for $\mathrm{RE}=\mathrm{La}$ and Pr. Here again, large $T_{c}$ values are due to the fact that ionic radii for these elements are rather high (1.160 and $1.126 \AA$, respectively). The ZFC magnetization shows a well defined peak, while the FC magnetization keeps increasing when decreasing the temperature, suggesting strong ferromagnetic $\mathrm{Co}^{2+}-\mathrm{Mn}^{4+}$ interactions.

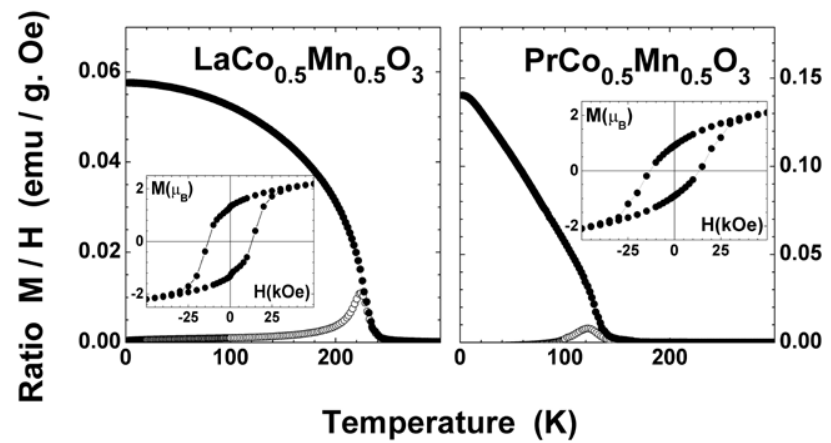

Fig. 2- ZFC (open symbols) / FC (filled symbols) magnetization cycles, measured at $250 \mathrm{Oe}$, for $\mathrm{RECo}_{0.50} \mathrm{Mn}_{0.50} \mathrm{O}_{3}(\mathrm{RE}=\mathrm{La}$ and $\mathrm{Pr})$. Inserts show the magnetization loops measured at $\mathrm{T}=2 \mathrm{~K}$. Ciclos de imanación ZFC (símbolos abiertos) / FC (símbolos cerrados), medidos a 250 Oe para $\mathrm{TRMe}_{050} \mathrm{Mn}_{050} \mathrm{O}_{3}(\mathrm{RE}=\mathrm{La}$ y Pr$)$. Los cuadros insertos muestran las curvas de magnetización medidas a $\mathrm{T}=2 \mathrm{~K}$

The ferromagnetic nature of the $\mathrm{RECo}_{0.50} \mathrm{Mn}_{0.50} \mathrm{O}_{3}$ compounds is confirmed by the magnetization loops performed at $2 \mathrm{~K}$, for varying applied fields between $-50 \mathrm{kOe}$ and $+50 \mathrm{kOe}$. Figure 3 shows the case of $\mathrm{NdCo}_{0.50} \mathrm{Mn}_{0.50} \mathrm{O}_{3}$ (right-hand panel), while inserts of figure 2 show the cases of $\mathrm{LaCo}_{0.50} \mathrm{Mn}_{0.50} \mathrm{O}_{3}$ and $\mathrm{PrCo}_{0.50} \mathrm{Mn}_{0.50} \mathrm{O}_{3}$. High coercive fields are observed in all these cases, typical of hard ferromagnets close to an ideal squared-shape hysteresis. On the contrary, the nickel-based compound $\mathrm{NdNi}_{0.50} \mathrm{Mn}_{0.50} \mathrm{O}_{3}$ (left-hand panel, fig. 3), differs quite significantly from its cobalt counterpart. In the case of nickel, a strong antiferromagnetic component is superposed to a soft ferromagnetic loop, confirming the hypothesis of the antiferromagnetic components seen by neutron diffraction experiments (18).
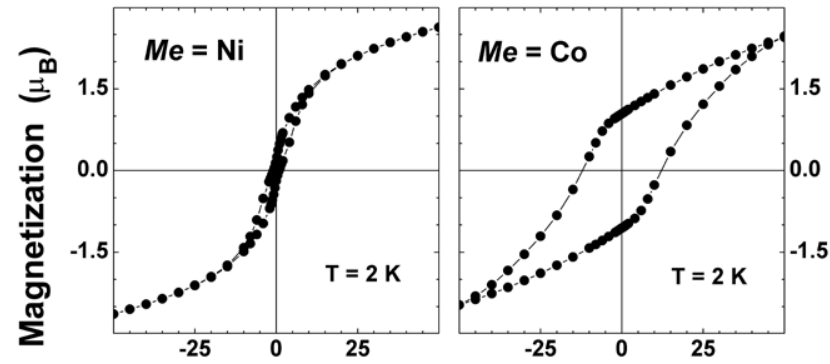

Applied Field (kOe)

Fig. 3- Magnetization loops measured at $\mathrm{T}=2 \mathrm{~K}$ for $\mathrm{NdMe}_{0.50} \mathrm{Mn}_{0.50} \mathrm{O}_{3}$ Curvas de magnetización medidas a $\mathrm{T}=2 \mathrm{~K}$ para $\mathrm{NdMe}_{0.50} \mathrm{Mn}_{0.50} \mathrm{O}_{3}$

\subsection{Heavy rare-earth elements}

When dealing with heavy rare-earth elements, two major modifications occur. Firstly, due to the well-known lanthanide contraction, their ionic radii are small compared to those of the light rare-earth elements discussed above, producing a strong lattice distortion and a net deviation of the $\mathrm{Mn}^{3+}$ $\mathrm{O}-\mathrm{Mn}^{4+}$ superexchange angle from the ideal value of $180^{\circ}$ expected for non distorted perovskites; as a consequence, the ordering temperature $\mathrm{T}_{c}$ is much lower, compared to the examples reported in §.3.1. Secondly, most of the heavy rareearth elements (with the exception of non-magnetic lutetium, or mixed-valents $\mathrm{Tm}$ or $\mathrm{Yb}$ ) have strong magnetic moments, much higher than those due to the transition metal network composed of $(\mathrm{Ni}+\mathrm{Mn})$ or $(\mathrm{Co}+\mathrm{Mn})$. Under such consideration, an exchange interaction may occur between two magnetic networks, the one due to the rare-earth element and the one due to the ferromagnetic $|\mathrm{Me}+\mathrm{Mn}|$ network.

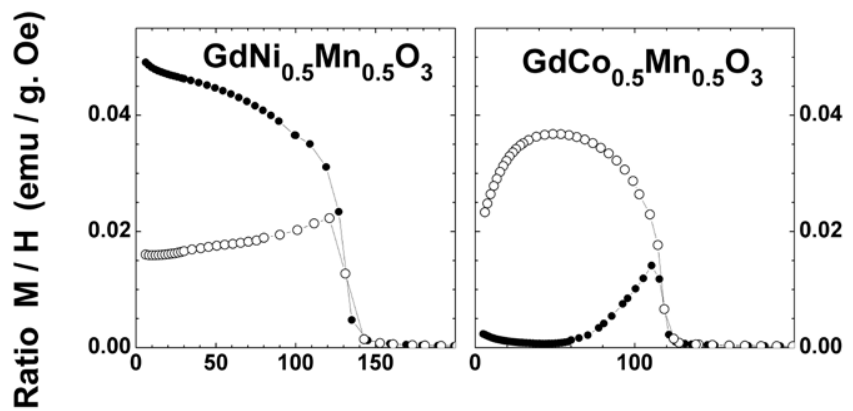

Temperature (K)

Fig. 4- ZFC (open symbols) / FC (filled symbols) magnetization cycles, measured at $250 \mathrm{Oe}$, for $\mathrm{GdNi}_{0.50} \mathrm{Mn}_{0.50} \mathrm{O}_{3}$ and $\mathrm{GdCo}_{0.50} \mathrm{Mn}_{0.50} \mathrm{O}_{3}$ Ciclos de imanación ZFC (símbolos abiertos) / FC (símbolos cerrados), medidos a 250 Oe para $\mathrm{GdNi}_{0.50} \mathrm{Mn}_{0.50} \mathrm{O}_{3}$ y $\mathrm{GdCo}_{0.50} \mathrm{Mn}_{0.50} \mathrm{O}_{3}$

Figure 4 shows the case of $\mathrm{RE}=\mathrm{Gd}$, i.e., $\mathrm{GdNi}_{0.50} \mathrm{Mn}_{0.50} \mathrm{O}_{3}$ and $\mathrm{GdCo}_{0.50} \mathrm{Mn}_{0.50} \mathrm{O}_{3}$, as it has been already reported by us in ref. (19). A similar behavior was also observed for the erbium cases, $\mathrm{ErNi}_{0.50} \mathrm{Mn}_{0.50} \mathrm{O}_{3}$ and $\mathrm{ErCo}_{0.50} \mathrm{Mn}_{0.50} \mathrm{O}_{3}$ (6) (not shown). In the case of the gadolinium nickel-based perovskite, the overall behavior is similar to the ones discussed before, that is, a flat plateau for the ZFC magnetization, characteristic of strong ferromagnetic $\mathrm{Ni}^{2+}-\mathrm{Mn}^{4+}$ interactions (20), which dominate the temperature dependence of the ZFC magnetization. Contrary to $\mathrm{Y}$ and $\mathrm{Nd}$ (figure 1), there is no abrupt decrease at low temperature, suggesting a less important antiferromagnetic contribution within the $\mathrm{Mn} / \mathrm{Ni}$ sublattice, perhaps due to crystallographic features. Unfortunately, the presence of gadolinium handicaps any further investigation of the magnetic structure through neutron diffraction techniques, as it was possible in the case of the Nd-based system (18).

In the cobalt-based samples the situation is much more interesting, since a pronounced decrease of the magnetization is observed during cooling, eventually becoming negative at lower temperatures (19). This original thermal dependence is due to the antiferromagnetic exchange interaction which settles between the Gd network and the transition metals, as discussed elsewhere $(5,19,21)$. Three basic ingredients are necessary for such a decrease of the magnetic moment and its eventual reversal: firstly, the rare-earth cation must have a large magnetic moment; secondly, the rare-earth spins must be considered as independent non-correlated moments; thirdly, a negative exchange interaction must exist between $\mathrm{RE}$ and $|\mathrm{Co}+\mathrm{Mn}|$. Then, the resulting magnetization would be the superposition of both contributions, depending on a subtle interplay between the thermal dependence of each 
sublattice. If the temperature is sufficiently low, then the rare-earth contribution (which varies as $\mathrm{T}^{-1}$ because of the non-coherent behavior of their spins) will overcome the constant contribution of the ordered $|\mathrm{Mn}+\mathrm{Co}|$ sublattice and, because of the negative exchange (that is, moments pointing in opposite direction), the total moment will start to decrease, reaching a compensation temperature (when $\left.\mathrm{M}_{\mathrm{Gd}}=-\mathrm{M}_{|\mathrm{Co}+\mathrm{Mn}|}\right)$ and becoming negative at still lower temperatures.

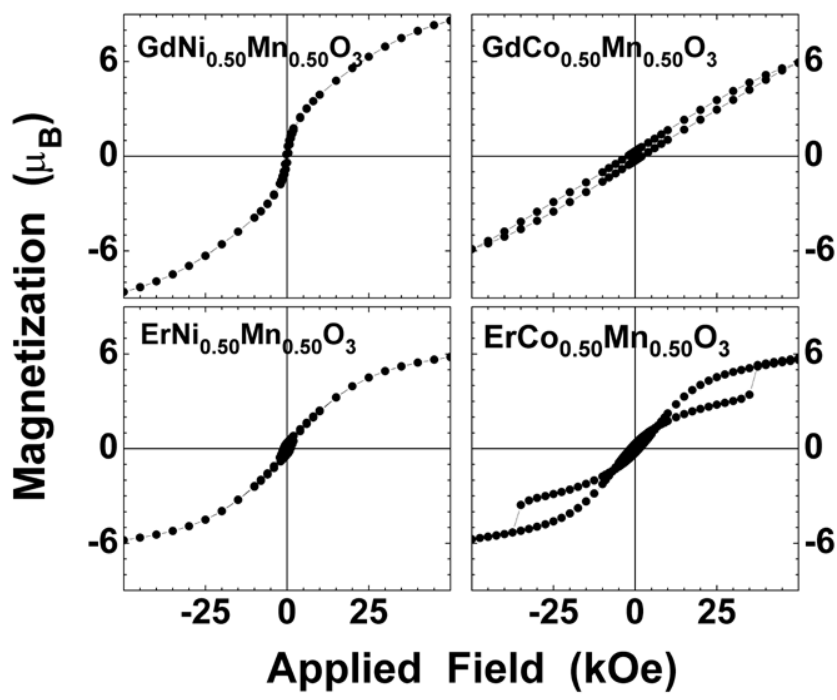

Fig. 5- Magnetization loops measured at $\mathrm{T}=2 \mathrm{~K}$ for given samples of $\mathrm{REMe}_{0.50} \mathrm{Mn}_{0.50} \mathrm{O}_{3}(\mathrm{RE}=\mathrm{Gd}, \mathrm{Er} ; \mathrm{Me}=\mathrm{Ni}, \mathrm{Co})$. Curvas de magnetización medidas a $\mathrm{T}=2 \mathrm{~K}$ para algunas muestras de $\mathrm{TRMe}_{0.50} \mathrm{Mn}_{0.50} \mathrm{O}_{3}(\mathrm{TR}=$ $\mathrm{Gd}, \mathrm{Er} ; \mathrm{Me}=\mathrm{Ni}, \mathrm{Co}$ )

Figure 5 compares the magnetization loops for characteristic samples of gadolinium and erbium perovskites. An important antiferromagnetic contribution is readily seen for nickel-substituted specimens, superposed to the classical Brillouin contribution of $\mathrm{Gd}$ moments. An almost negligible hysteresis is observed, with coercive fields of the order of 300 and $1200 \mathrm{Oe}$, for RE = Gd and Er, respectively. Cobalt-based samples are quite different from the previous ones. In figure 5, the magnetization loop of $\mathrm{GdCo}_{0.50} \mathrm{Mn}_{0.50} \mathrm{O}_{3}$ is not completely closed on itself, and higher applied fields are necessary to evaluate exactly the coercive fields. However its $\mathrm{H}_{\text {coer }}$ value seems to be quite low, of the order of 2000 Oe, much smaller than the values obtained for the non-magnetic rare-earth in $\mathrm{YCo}_{0.50} \mathrm{Mn}_{0.50} \mathrm{O}_{3}$ (of the order of $10 \mathrm{kOe}(17)$ ), suggesting that the antiferromagnetic component dominates. $\mathrm{ErCO}_{0.50} \mathrm{Mn}_{0.50} \mathrm{O}_{3}$ constitutes a very special and original case which is discussed thoroughly elsewhere $(22,23)$. For completeness we recall that this system is characterized by two well-defined anomalies in the magnetization loop: one at rather low field, where the increasing and decreasing branches intersect, and another anomaly at high fields, where a sudden jump occurs. The first anomaly is related to the spin reversal phenomenon, since it disappears immediately above the compensation temperature. The second anomaly has a dynamical character since it depends on the sweep-rate of the applied field (23), and it is probably related to a motion of the domain walls. Additional observations performed in the $\mathrm{Er}_{x} \mathrm{Y}_{1-\mathrm{x}} \mathrm{CO}_{0.50} \mathrm{Mn}_{0.50} \mathrm{O}_{3}$ system (24) lead us to conclude that the high-field jump is certainly related to a re-orientation of the domains walls under the influence of the applied field.

\section{CONCLUSION}

As a general conclusion, we might say that nickel-based and cobalt-based systems behave differently with respect to the $\mathrm{ZFC} / \mathrm{FC}$ and the magnetization cycles. Strong ferromagnetic $\mathrm{Ni}^{2+}-\mathrm{Mn}^{4+}$ interactions are observed in all compounds studied in this work, characterized by a flat plateau of large absolute value during the initial warming of the zero-field-cooled process. During the field-cooled process, a sharp decrease of $\mathrm{M}^{\mathrm{FC}}$ is usually observed due to antiferromagnetic interactions within the transition metal lattice (observed for non-magnetic $\mathrm{Y}$ and $\mathrm{La}$ and low-magnetic $\mathrm{Nd}$ and $\mathrm{Eu}$ ). The cobalt-based samples show a steady increase of $\mathrm{M}^{\mathrm{FC}}$ when cooling, if the rare-earth is a light element.

Quite different results were obtained in the case of heavy rare-earths bearing a large magnetic moment, such as Gd and Er. In this case, a significant inter-sublattice exchange interaction of antiferromagnetic nature between two magnetic sublattices ( $\mathrm{RE}$ and $|\mathrm{Co}+\mathrm{Mn}|$ ) leads to a reversal of the total magnetic moment, as if the system was of ferrimagnetic type.

Magnetization loops also show different behaviours depending if the transition metal substitute is nickel or cobalt. For all nickel-based compounds studied in this work, an antiferromagnetic-like variation predominates over small ferromagnetic loops. On the contrary, cobalt-based samples show much larger coercive fields, as if the $\mathrm{Co}^{2+}-\mathrm{Mn}^{4+}$ interactions were much stronger than the $\mathrm{Ni}^{2+}-\mathrm{Mn}^{4+}$ ones. Special mention is deserved to the $\mathrm{ErCo}_{0.50} \mathrm{Mn}_{0.50} \mathrm{O}_{3}$ material, for which a steplike transition at high fields due to a reorientation of magnetic domains, and an intersection of the increasing and decreasing branches, were observed.

\section{ACKNOWLEDGMENTS}

Authors acknowledge the bilateral exchange program France-Spain CNRS-CSIC, project $\mathrm{n}^{\circ} 18873$, and national project from Chilean government, FONDECYT 11060462.

\section{REFERENCES}

1. C.N.R. Rao and B. Raveau (eds), Colossal magnetoresistance charge ordering and related properties of manganese oxides. World Scientific, Singapore, 1998

2. Y. Tokura, Colossal magnetoresistive oxides. Gordon \& Breach, New York, 2000

3. J.M.D. Coey, M. Viret, S. von Molnar, Mixed-valence manganites, Advances in Physics, 48, 167-293 (1999)

4. C. Zener, Interaction between the d-Shells in the Transition Metals. Ferromagnetic Compounds of Manganese with Perovskite Structure, Phys. Rev. 82, 403-405 (1951)

5. O. Peña, C. Moure, P. Barahona, M. Baibich, G. Martinez, Intra- and internetwork interactions in magnetic oxides, Physica B, 384, 57-61 (2006)

6. O. Peña, A.B. Antunes, M.N. Baibich, P.N. Lisboa-Filho, V. Gil, C. Moure, Spin reversal and magnetization jumps in $\mathrm{ErMe}_{\mathrm{x}} \mathrm{Mn}_{1-\mathrm{x}} \mathrm{O}_{3}$ perovskites $(\mathrm{Me}=$ Ni, Co), J. Magn. Magn. Mater., 312, 78-90 (2007)

7. A.B. Antunes, V. Gil, C. Moure, O. Peña, Magnetic properties of $\operatorname{Er}(\mathrm{Co}, \mathrm{Mn})$ O perovskites, J. Europ. Ceram. Soc., 27, 3927-3930 (2007)

8. M. Mouallem-Bahout, T. Roisnel, G. André, D. Gutierrez, C. Moure, O. Peña, Nuclear and magnetic order in $\mathrm{Y}(\mathrm{Ni}, \mathrm{Mn}) \mathrm{O}_{3}$ manganites by neutron powder diffraction, Solid State Commun., 129, 255-260 (2004)

9. I. O. Troyanchuk, N. V. Samsonenko, E. F. Shapovalova, H. Szymczak and A. Nabialek, Synthesis and characterization of $\operatorname{Ln}\left(\mathrm{B}_{0.5} \mathrm{Mn}_{0.5}\right) \mathrm{O}_{3}$ (Ln-lanthanoid; $\mathrm{B}=\mathrm{Ni}$, Co) perovskites, Mater. Res. Bull., 32(1), 67-74 (1997)

10. F. Gao, R.A. Lewis, X.L. Wang, S.X. Dou, Phonon modes of $A\left(\mathrm{Co}_{1 / 2} \mathrm{Mn}_{1 / 2}\right) \mathrm{O}_{3}$ $(\mathrm{A}=\mathrm{La}, \mathrm{Nd}, \mathrm{Dy}, \mathrm{Ho}, \mathrm{Yb})$, J. Solid State Chem., 160, 350-352 (2001)

11. C. Campos, G. Pecchi, Y. Moreno, C. Moure, V. Gil, P. Barahona, O. Peña, Mn-substituted perovskites $\mathrm{RECo}_{x} \mathrm{Mn}_{1-x} \mathrm{O}_{3}$ : a comparison between $\mathrm{LaCo}_{\mathrm{x}} \mathrm{Mn}_{1-\mathrm{x}} \mathrm{O}_{3}$ and $\mathrm{GdCo}_{\mathbf{x}} \mathrm{Mn}_{1-\mathrm{x}} \mathrm{O}_{3^{\prime}}$ this conference, Bol. Soc. Esp. Ceram. V., accepted (2008) 
12. C. Moure, D. Gutierrez, O. Peña, P. Duran, Structural characterization of $\mathrm{YMe}_{\mathrm{x}} \mathrm{Mn}_{1-\mathrm{x}} \mathrm{O}_{3}(\mathrm{Me}=\mathrm{Cu}, \mathrm{Ni}, \mathrm{Co})$ perovskites, J. Solid State Chem., 163, $377-384^{x}(2002)$

13. C. Moure, D. Gutierrez, O. Peña, P. Duran, Effect of the processing parameters on the crystalline features of the solid solution $\mathrm{Y}\left(\mathrm{Co}_{\mathrm{x}} \mathrm{Mn}_{1-\mathrm{x}}\right) \mathrm{O}_{3^{\prime}} \mathrm{x}$ $=0.6,0.7$, J. Am. Ceram. Soc., 86, 54-58 (2003)

14. R.D. Shannon, Revised effective ionic radii and systematic studies of interatomic distances in halides and chalcogenides, Acta Cryst., A32, 751-767 (1976)

15. J.B. Goodenough, Localized-itinerant electronic transitions in oxides and sulfides, J. Alloys Compounds, 262-263, 1-9 (1997)

16. M. Hennion, F. Moussa, J. Rodriguez-Carvajal, L. Pinsard, A. Revcolevschi, Coherent waves of magnetic polarons propagating in $\mathrm{La}_{1-\mathrm{x}} \mathrm{Ca}_{\mathrm{x}} \mathrm{MnO}_{3}$ : $\mathrm{An}$ inelastic-neutron-scattering study, Phys. Rev. B, 56(2), R497-R500 (1997)

17. D. Gutiérrez, O. Peña, K. Ghanimi, P. Durán, C. Moure, Electrical and magnetic features in the perovskite-type system $\mathrm{Y}(\mathrm{Co}, \mathrm{Mn}) \mathrm{O}_{3^{\prime}}$ J. Phys. Chem. Solids, 63, 1975-1982 (2002)

18. M. Mouallem-Bahout, T. Roisnel, F. Bourée, G. André, C. Moure, O. Peña, Neutron diffraction evidence for a cationic order in the $\mathrm{REMn}_{05} \mathrm{Ni}_{05} \mathrm{O}_{3}$ (RE $=\mathrm{La}, \mathrm{Nd}$ ) and $\mathrm{YMn}_{0.5} \mathrm{Co}_{0.5} \mathrm{O}_{3}$ perovskites, Prog. Solid State Chem., 35, 257$264(2007)$
19. O. Peña, A.B. Antunes, G. Martínez, V. Gil, C. Moure, Inter-network magnetic interactions in $\mathrm{GdMe} \mathrm{Mn}_{1-\mathrm{x}} \mathrm{O}_{3}$ perovskites $(\mathrm{Me}=$ transition metal) J. Magn. Magn. Mater., 310, 159-168 (2007)

20. G. Blasse, Ferromagnetic interactions in non-metallic perovskites, J. Phys. Chem.. Solids, 26(12), 1969-1971 (1965)

21. O. Peña, M. Bahout, K. Ghanimi, P. Durán, D. Gutiérrez, C. Moure, Spin reversal and ferrimagnetism in $(\mathrm{Gd}, \mathrm{Ca}) \mathrm{MnO}_{3^{\prime}}$ J. Mater. Chem., 12, 2480-2485 (2002)

22. A.B. Antunes, O. Peña, C. Moure, V. Gil, G. André, Structural and magnetic properties of $\operatorname{Er}(\mathrm{Co}, \mathrm{Mn}) \mathrm{O}_{3}$ perovskite, J. Magn. Magn. Materials, 316, e652-e655 (2007)

23. A.B. Antunes, O. Peña, C. Moure, G. Martinez, M.N. Baibich, Network interactions and dynamical phenomena in magnetic oxides, J. Magn. Magn. Materials, 316, 404-409 (2007)

24. A.B. Antunes, M.N. Baibich, C. Moure, V. Gil, V. Allegret-Maret, O. Peña, Field-induced transitions and magnetization reversal in $\operatorname{Er}_{x} \mathrm{Y}_{1-\mathrm{x}} \mathrm{Co}_{0.50} \mathrm{Mn}_{0.50} \mathrm{O}_{3}$ $(0.0 \leq x \leq 1.0)$, this conference, Bol. Soc. Esp. Ceram. V., accepted (2008) 